ISSN: 2707-756X

DOI: $10.32996 /$ jeltal

Journal Homepage: www.al-kindipublisher.com/index.php/jeltal

\title{
Implementing Cooperative Integrated Reading and Composition (CIRC) Method to Enhance the Reading Comprehension of Indonesian EFL Learner
}

\author{
Rafi'ah Nur \\ English Language Education Department of Graduate Program Universitas Muhammadiyah Parepare, Indonesia \\ $\square$ Corresponding Author: Rafi'ah Nur, E-mail: rafiahnur@yahoo.com
}

\begin{abstract}
ARTICLE INFORMATION ABSTRACT
Received: 04 September 2021

Accepted: 25 October 2021

Published: 31 October 2021

DOI: 10.32996/jeltal.2021.3.11.7

\section{KEYWORDS}

CIRC, Reading Comprehension, Language Teaching, Cooperative Learning, integrated learning

The objective of this research is to reveal the application of the Cooperative, Integrated Reading and Composition (CIRC) method to increase the reading comprehension of Indonesian EFL learners at junior schools. The CIRC method is one of the teaching methods that English teachers adjust to encourage their students to learn reading comprehension (Gupta \& Ahuja, 2015); Zarei, 2012). One reason the researcher investigates reading is in the late time, the EFL learners are very less to spend their time on their reading habits (Derinalp, 2021). The EFL learners are very less to spend their time on their reading habits (Fan, 2016). Reading comprehension is one of the important skills of a language. Much information from the text form problematic issues (Riazi, 2017). It needs a complex skill to acquire this language skill. Therefore, the language learner who concerns with transforming information must prepare a strategy to work. This research applied a quasi-experimental method with a non-equivalent control group design. This study took the junior high school students in Parepare, Indonesia, as its subjects. Two groups of students were involved in the study, one as an experimental group and one as the control group. The data were collected using a comprehension test of the reading content. Management of analytical data was tested by the t-test and the accumulation of the percentage value. The results showed that CIRC improves the reading comprehension of Indonesian junior high students.
\end{abstract}

\section{Introduction}

Reading is exploring information activity in a particular proposes which are expected to engage (St Clair et al., 2017). People have some reasons to read an article in their activity, for instance, to collect information and see the truth or (verification) of information conveyed through the results of critical thinking by the author. The readers also carry out a communication process through the reading method. It is intended to increase the quality of their language understanding of an article presentation.

Reading as a complex language skill operates maximum cognitive process and some aspect of communication to have information in the task of text (Wicramaarachchi, 2016). In connecting learners' minds to the text material, the learners must empower their language competencies to comprehend the critical information presented by the writer (Mudra, 2020). The same idea was from Grabe and Stoller (2011), who said that reading activity is formally used to search for simple information or integrate information and learn information through text. Further, Castle et al. (2018) stated that the students should be in good preparation for reading activities when they plan to go to university.

Reading activities involves people grasping ideas from the text. Richards (2010) reveals that perceiving a written text to comprehend the contents can be done in silence when dealing with reading activities. This process requires comprehension. Regarding comprehension in reading, Wooley (2011) also commented that reading activity is an attempt to get meaning from the text. For that reason, reading aims to get a thorough understanding of the things described in the paragraph rather than gaining understanding or meaning on a pre-sentence or word-by-word basis.

Copyright: (C) 2021 the Author(s). This article is an open access article distributed under the terms and conditions of the Creative Commons Attribution (CC-BY) 4.0 license (https://creativecommons.org/licenses/by/4.0/). Published by Al-Kindi Centre for Research and Development, London, United Kingdom. 
Healy (2002) asserts that reading comprehension takes purpose and point of the written text, knowledge of the content of the text read, and the construction of the text's overall meaning. Therefore, reading is an active activity (Castles et al., 2018). A reader reads to understand, remember what is felt, and place his understanding using the oral journal (Subramanyam, 2013). People read the text to understand what is understood, but the understanding is in an oral journal (Subrama, 2013). This definition concludes that reading is a communication process between a writer and a reader by thinking activity to understand and get meaning, information, and ideas that are expressed by the writer in the text directly.

In general, reading consists of two types, namely intensive reading and extensive reading. Each type of reading has a different definition and characteristics (Harmer, 2001). Both definitions explain that reading is another form of language skill.

Brown (2007) explains that intensive reading appeals to students to pay attention to grammar patterns, discourse markers, and other surface structure circumstances to conceive literal meaning, intention, and rhetorical relationships. It can also proceed as a zoom-lens strategy because the reader takes a closer look at the manuscript (Goodman, 1995).

This study intended to investigate the effectiveness of the CIRC in teaching reading comprehension to junior high school students in Parepare, Indonesia. The research will contribute to language teaching, especially in teaching reading skills to junior high schools in Indonesia. This research implied that cooperative learning could make the language teaching process more effective.

\section{Literature Review}

In practical life, reading activity is used to comprehend contracts, business articles, memorandums, application forms, and legal documents (Channa et al., 2016). Therefore, intensive reading equips students with basic reading strategies to permit them to attain fluency and competence in the fields of vocabulary recognition and to increase their critical thinking skills (Jeanne Wanzek, 2014). Therefore, the students must precisely understand the text details, facts, concepts, opinions, and experiences (Sevilla, 2017). A message occurs in discourse; alongside, the purpose of intensive reading is to promote the reading ability in comprehending the whole contents of text (Miftah, 2015).

The second type is extensive reading. Brown (2007) illustrates that extensive reading activities are reading activities to understand information whose text presentation is quite long, for example, reading books or articles. Extensive reading is frequently undertaken outside the classroom in free time. Extensive reading is conducted for pleasure and usually takes a long time because of the long texts (Prowse, 2005).

Furthermore, Hamer (2001) stated that the main consideration in extensive reading activities is that readers are expected to collect reading material that they are familiar with. If the readers attempt to understand every word in the reading text, then they are almost categorized as not reading for pleasure as much as they want to achieve the goal of extensive reading.

(Halonen et al., 2012). Extensive reading means reciting longer texts, usually for pleasure. This process is a fluency activity, mainly encompassing broad understanding (Grellet, 1981).

Another concept, from Akbar et al. (2015), shows that the purpose of extensive reading is to gain comfort. Based on this assumption, extensive reading does not have to use a dictionary to understand the content of the reading. Extensive reading can possess a positive effect on language proficiency, especially at the level of reading speed (Bamford \& Day, 2004,). Bamford continuously stated that extensive reading can motivate learners to always be responsible for the reading progress they have achieved and cultivate the practice of reading activities that are not only looking for information but also for fun.

Bamford \& Day, 2004) stated some characteristics of extensive reading material; namely, material availability is various on a wide range of topics, pleasure, information, and general understanding. It is usually faster rather than slower, and it is individual and silent activities (Azmuddin, 2014). For this reason, the researcher can define that extensive reading as a process of reading where people read just for pleasure and emphasis on general understanding, not for specific information. The reader learns and chooses the topic that they want to read. Mostly, people read the comfortable material that does not need to look up words of English to understand the text.

In short, reading is a language skill that requires quite complex competence to obtain the information presented in the reading text. The information indicates that there must be an integrated communication, even relation, between the readers and the writer, which aims to build knowledge and meaning of the text. This reading definition also reveals that the critical thing in the reading process is to construct and understand the contents of the document. The meaning of a document is a combination of text, background, and the expériences of the reader.

\subsection{The levels of reading comprehension}


Reading comprehension is an active thinking activity that involves the experience and knowledge of students. The experienced knowledge can be in terms of learning to read and reading to learn in English (Kispal, 2008). The student who has a high level of thinking, prior knowledge will be successful in reading comprehension (Alhaisoni, 2017).

Reading comprehension can be derived into several levels. A higher level of understanding includes a more elevated level of thinking. Miftah (2015) argues four levels in reading comprehension. The first level is literal understanding. Miftah (2015) explains that the essence of the purpose of this literal understanding is to identify the main ideas that have been stated in detail, including cause and effect and their sequence. This subject is very basic to be a prerequisite for high-level comprehension ability. The second level is interpretive understanding. This reading level works on inferring the main ideas of texts in which the main purposes are not directly stated, reckoning cause-and-effect relations when they are not directly stated, deciding referents of pronouns, holding referents of adverbs, guessing omitted words, and drawing a conclusion. The third level is critical reading. At this level, the reader conducts an evaluation of written materials, comparing the ideas found with a prominent standard and concluding the inaccuracy, properness, and timeliness. The serious readers must be active readers, asking questions, investigating facts, and postponing judgment until they have considered all of the materials. The last level is creative reading. In creative reading, the readers are involved to exceed the materials provided by the author. The readers are required to think while reading. To apply the level of creative reading in the classroom, teachers must model the thought processes covered.

\subsection{Assessment in reading comprehension}

To make our reading comprehension beneficial, we have to conduct an assessment of the reading progress. There are some types of assessment in reading comprehension. Torgesen (2006) mentions four types of assessment carried out for a comprehensive reading assessment. These reading assessments comprise screening tests, progress monitoring tests, diagnostic tests, and reading outcome tests. Each kind of evaluation is essential in its own right and provides valuable information.

\subsubsection{Screening tests}

The screening assessment aims to track the level of student difficulty in reading. It is very important to conduct an early search on the level of reading difficulty of children. The teacher can do the development of intervention plans that hopefully prevent reading deficits. A reliable and reliable selection test will help teachers distinguish the impact of the learning process they are doing and can be understood by the learner.

\subsubsection{Progress monitoring tests}

The purpose of the progress monitoring test is to decide whether the students are performing sufficient progress. Once the students are identified as at risk for reading difficulties, so the intervention plan is developed. There are two kinds of progress monitoring tests, namely: curriculum-embedded and general analysis. The embedded curriculum test is intended to find out groups of students who have understood the material and find out whether the group or class being taught is ready to move on to the next discussion material. The general analysis is intended to evaluate and critically assess reading skills, examples, use of phonemes, vocabulary selection, and comprehension of reading content.

\subsubsection{Diagnostic tests}

Diagnostic assessment serves to provide data to the evaluation team (teachers) about learner skills. The diagnostic test should be given when there is reliable information about the students' Difficulty in reading (difficulty) is useful for providing guidance in making more established plans.

\subsubsection{Reading outcome tests}

The reading outcome test is carried out at the end of the current year period. This test is often done in groups. One example is the reading comprehension test. This type of test will provide feedback to teachers about all types of their reading activities that have been programmed.

Based on those explanations, it can be claimed that reading assessments are used to determine the quality of students' works in reading. In this case, to know the extent to which the students understand and make progress of the subject that is presented by the teacher. The assessment also is used to identify and diagnose students who are a risk for reading difficulties (Alberto et al., 2014) (Latifa et al., 2015)

\subsection{CIRC Method}

Regarding cooperative, integrated, reading, and integrated composition (CIRC), Gupta \& Ahuja (2015) argue that cooperative learning is a type of approach in learning that emphasizes students to work together in groups to complete academic work based on the group's goals. Furthermore, Gupta \& Ahuja (2015) said that the members of the group carried out a debate process from 
their respective points of view to resolve the problems raised in the group assignments. Students are not charged to work as they are in a team but to learn something as a team. Slavin (1996) stated that in a cooperative learning strategy, the students are left to learn something as a team, but they are not required to be a continuous team beyond the group. Therefore, students can achieve their learning goals when working in groups only. Working together in two heads is better than in just one because we can help each other in learning instructional alternatives.

A popular term is that two heads are much better than one in exchanging ideas and opinions while studying. As with instructional options, teachers who take advantage of this approach must really be very established presenters in front of the class. He must have multi-dimensional insight and be able to carry out team tasks at a more positive achievement and can monitor the activities of the work team, be able to diagnose problems that arise and provide solutions.

Slavin (1986) and Stevens (1987) argued that CIRC was sourced from research and development. This type of research is widely used for learning reading and writing (Cruickshank et al., 2006) and is easy to use in performing the teaching of reading and writing skills (Erhan, 2011). An additional view is from Richardson, and Morgan (2003) argues that in the CIRC approach, the learning director or instructor (teacher) utilizes the main reading text and traditional reading units but assigns assignments to the students in pairs from different groups of reading class to meet for working on particular tasks, for example, the student can understand the work to each other. In this pair work, students can estimate their reading comprehension, summarize their story, write down their responses to the story. They can work together to get the main idea, choose the right vocabulary through this group work.

It is entirely that the CIRC is helpful for the teacher To design, implement and conduct an evaluation process for language teaching, especially in writing and reading skills (Stevens, et., al1987). Gupta and Ahuja (2015) stated that CIRC encourages higher student achievement into more social and academic interactions. Gupta and Ahuja, (2015) argue that the CIRC approach motivates students to be more academic and social in interacting. By using the CIRC approach, learners have been instilled in contemporary ways of thinking when they interact in pairs.

Further, Vygotsky (1978) stated that the ideas verification, the strategy planning for task completion, the politeness protocols, consensus searches, compromises, and the symbolic representation of other intellectual acts are stipulated through peer communications. To reach the goal of the CIRC approach, the teacher must follow the important element of CIRC. Slavin (2005) has some classification, namely reading groups, teams, and story related.

\subsubsection{Reading groups}

Students are deputed to two or more reading groups according to their level, as set by their teacher. Alternatively, instructions are given to the whole class. Students are given assignments in reading groups based on their level of ability. If not, then instructions are assigned to all groups in the class.

\subsubsection{Teams}

Students are given tasks in pairs in groups whose task is to read. Then, pairs were formed with two groups based on their reading ability, namely the group with high reading comprehension ability and the low Abilify group. Team members receive scores based on the results of answers to all questions on quizzes, writing, and notes in the form of reports and these points from the scores of the high reading team and two of the two low ability groups.

\subsubsection{Story related}

Learners take advantage of novels or novice readers. The story from the novel is presented in the reading group and then discussed accompanied by the teacher. In this group mentoring, the teacher conveys the learning objectives, teaches vocabulary, and immediately analyzes the content of the story after the students do reading. The results of the discussion of the novel were compiled by students with the intention of honing their skills in making predictions, sorting out problems in reading texts. After the documents are discussed together, students are given assignments in the form of story packages containing a number of reading activities. Next, they discuss in groups.

In short, cooperative, integrated reading and composition (CIRC) method students work with partners during reading, decode, story structure, predict, and summarize story related to storiesLearners get directions on how to understand the text in the reading assignment and complete the task of reading comprehension in their group. Finally, they can be more motivated to learn to increase their quality to skillfully understand the information on the reading.

\subsection{The steps of the CIRC method}


Teaching reading by CIRC method indeed consists of some steps to make it effective. The activities are more detailed revealed by Slavin (2005) into ten stages. Firstly, the students read the story aloud with a partner, take turns for each paragraph. Meanwhile, the listener emends any errors made by the reader. The teacher assesses the results of the learners' work takes turns and listens while students read to each other. Secondly, students are assigned a task to answer questions related to the story. The purpose of this assignment is to measure students' ability to operationalize grammatical skills to understand story content. After reaching half of the story, the students were commanded to stop reading, sort out the characters, find out the background of events, and give predictions about how the issue could be solved. Thirdly, the students practice saying the list of difficult words in the passage could pronounce correctly until smooth. Fourthly, learners are provided with lists of words to memorize and understand. Then, they are facilitated with a dictionary to show the translation and meaning of the new words. Fifthly, after reading the story and discussing it in their reading teams, students conclude the main points of the story with their partners. Sixthly, the students are tested each spelling list of words to each other every week for the next program of activities during the week to help each other to master the list. Seventhly, the students have to complete all of the activities. Their partner will give them the task indicating that they have completed and reached the requirements for a good task. Eighthly, the students were given a test of understanding the story. Ninthly, the teacher instructs direct teaching to students how to comprehend the reading by tracing the main idea. In addition, the teacher conveys how to understand and explore causality in the discourse on the reading and then make conclusions to the learners. Tenthly, the students are involved in integrated language arts and assigned writing. It emphasizes writing on processes where students are familiarized to language mechanics skills as special aids in composing a writing draft. The students' compositions are altered after consulting teammates and the teacher about their ideas and organization. Students work in groups as a team to improve the content of their compositions. They then make editing on their workmates' drafts by using peer editing forms. These team revisions emphasize mechanical and grammatical correctness.

\subsection{The advantages and disadvantages of the CIRC method}

Applying the CIRC method in teaching has many advantages and disadvantages. The benefits are to enhance students' skills to solve problems, to decrease the teacher dominance in learning, and to motivate the students to have accurate results in their work (Irma (2013). The other advantages are to help the student to get understanding the meaning of questions of each job, to help weak the students, to improve the learning outcomes, to put the relevance between Experience and learning activities students and the child's developmental level. The disadvantages of CIRC, on the other hand, include several activities that are quite diverse in each activity. Almost all businesses need time to reach the target. Therefore, proper time allotments are strongly recommended.

\subsection{Conceptual Framework}

The conceptual framework of the research consisted of three parts; there were input, process, and output.

\subsubsection{Input}

Reading comprehension is the capability of the reader to provide information in the reading text. This activity involved the readers' understanding of what they learned. Woolley (2011) stated that reading comprehension is a process of getting meaning from text. Therefore, the goal is to obtain an overall understanding of what is expressed in the paragraph rather than to achieve sense from separated words or sentences. However, mastering reading comprehension is not an easy matter. The reading comprehension of the eighth-year students of junior high schools in Parepare was low. There were some students who were unsuccessful in comprehending the reading text.

In conducting reading comprehension instruction, therefore, the teacher should concern with principles in teaching reading for achieving the goals of the learning process well. Reading is not a passive skill, but it is an incredibly useful active work (Harmer, 1998). To do it effectively, we have to achieve what the words imply. Harmer (1998) also claimed that good teachers make full use of reading texts. The teacher integrates the reading text into interesting learning sequences, uses topics for further discussion and assignments, and uses language for further learning and activation.

Therefore, this study tried to solve problems of reading comprehension of the eighth-year students of junior high schools in Parepare through the cooperative, integrated reading and composition (CIRC) method. The CIRC method is a collaborative learning model that emphasizes group goals and individual responsibility. The aim was to generate opportunities for the students to better understand the materials in a learning process. In this case, the students were involved in some activities, pairs, group discussions, and whole-class discussions. Therefore, the students achieved a profound comprehension of the passages that they have recited.

The CIRC has been successfully used as a comprehensive program for teaching reading and writing in upper elementary grades (Slavin, 2006). The students were involved in four-member collaborative learning teams. They are engaged in a sequence of activities in teamwork, including reciting peers' drafts, making predictions about the end of the stories, summarizing stories 
together, writing a response to the story, and exercising spelling, decoding, and practicing vocabulary. The students also work in groups to discover the main idea and achieve other comprehension skills.

\subsubsection{Process}

The researcher introduced the reading material about the narrative text to the students that consisted of three topics. They were: the Legend of Sura and Baya, Snail, Dragonfly, and Toad, Snow White, and The King of the Mice and the Woodcutter.

The materials were delivered in two classes through different treatment of teaching implementation. In the experimental group, the learners were taught reading material through the CIRC method. In the CIRC, the students were designed to do activities in the learning process by group discussion such as; reading pair, making a prediction of how the story will come out, vocabulary, practicing spelling, decoding, story retell and making a summary. While in the control group, the learners were taught reading material through individual learning. The students were designed to do activities in the learning process individually, such as; reading the text, making a prediction of how the story will come out, vocabulary, practicing spelling, decoding, story retell and making a summary of a text.

\subsubsection{Output}

In the output, the researcher gave reading comprehension tests in both experimental and control classes to measure the students' improvement after giving treatments to each class. The test consisted of twenty items where ten items were in the form of multiple choices, five items of true-false, and five items of filling the blanks. The researcher was required to provide meaningful progress on reading comprehension activities after learning through the CIRC approach.

The conceptual framework of this research gives us the following diagrams:

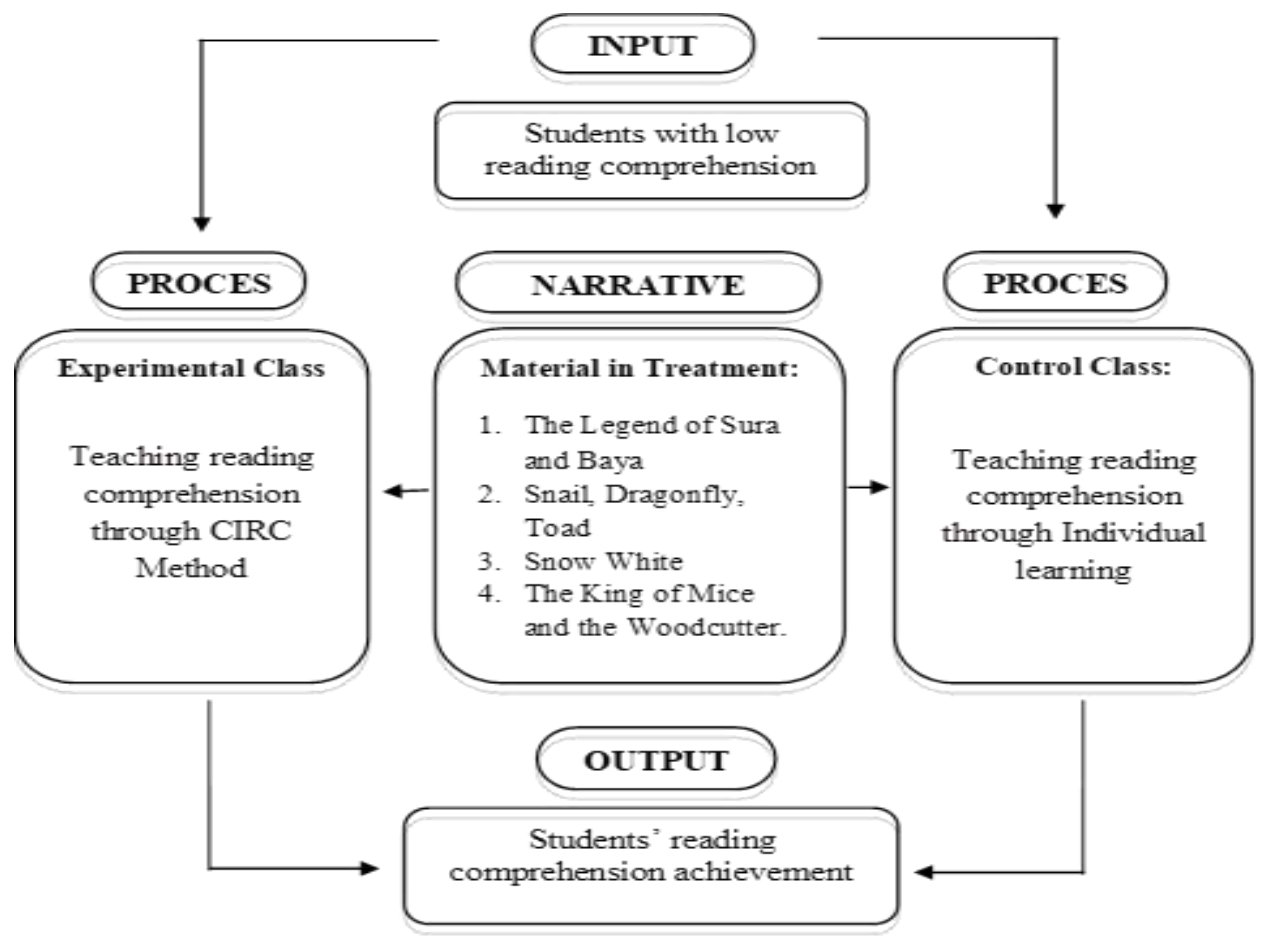

Figure 2.1: The conceptual framework

\section{Methodology}

The research design applied to this research was quasi-experimental with a non-equivalent control group design. The study involves two classes with different treatments (Gay et al., 2012). They are experimental class and control class. The design of the study is shown in figure 1. O represents the pre-test, and post-test applied to the experimental and the control group. The X1 and $\mathrm{X} 2$ served teaching strategies given to the experimental and control groups. The experimental group used the CIRC method, while the control group used an individual learning strategy in learning reading. This design is captured by Gay (2012) in the following figure. 


\begin{tabular}{lcccc}
\multicolumn{2}{c}{ Class } & Pre-test & Treatment & Post-test \\
Experiment & $\mathrm{O}$ & $\mathrm{X} 1$ & $\mathrm{O}$ & \\
Control & $\mathrm{O}$ & $\mathrm{X} 2$ & $\mathrm{O}$ &
\end{tabular}

Figure: 1 Gay, et al (2012)

In this research, the researcher used four times treatments in both groups, the experimental group and the control one, that were conducted after the pre-test. The population of the study was the students of Junior high schools of Parepare-Indonesia in the academic year 2014/2015, which consisted of nine classes. The sample was 78 students that were selected by using the simple random technique. Both the experimental class and control class received the same test. The test was in the form of reading a narrative text.

The collecting data was conducted in two stages. The pre-test was applied to discover the prior ability of the students' reading comprehension before treatment. The students, both in the experimental class and control class, were assigned to answer twenty questions that were raised from a narrative text reading. In the experimental class, a post-test was to measure the progress of students' reading comprehension after being treated through the CIRC method. The students were assigned to answer questions that related to the reading narrative text. The researcher gave conducted four treatments for both the experimental group and the control one. The time allocation is 80 minutes for each treatment.

To analyze the data that was collected through pre-test and post-test, the researcher used the following procedures.

1) Scoring the students' correct answer

2) Classifying score

3) Classifying scores into five classifications by using the National Standard of Indonesia (2014).

4) Calculating the rate percentage of the student's score

5) Calculating the mean score of the students

6) Calculating the standard deviation

7) Testing hypothesis

\begin{tabular}{|c|c|c|c|c|}
\hline Ordinal Scores & Qualitas & Level Degree & $\begin{array}{l}\text { Conversion } \\
\text { Scores }\end{array}$ & Level Degree \\
\hline 4 & Sangat bagus & Excellent & $86-100$ & Very good \\
\hline 3 & Bagus & Good & $71-85$ & Good \\
\hline 2 & Cukup & Fair & $56-70$ & Fair \\
\hline 1 & Kurang & Poor & $41-55$ & Poor \\
\hline $0-0,9$ & Sangat kurang & Very poor & $<40$ & Very poor \\
\hline
\end{tabular}

Figure: 2, National Education Standard of Indonesia, (2014, P.12-13)

To discover the significant difference in the mean score of reading comprehension between pre-test and post-test, the researcher calculated the value of the t-test. The researcher used a t-test for an independent sample to test the hypothesis. A two-tailed test was applied.

\section{Results and Discussion}

\subsection{Results}

In finding out the students' reading comprehension, the researcher applied all procedures that had been shown in the previous section. The researcher gave pre-test and post-tests to the students, both the experimental group and control one. The result of each test was different. The analysis was continued to analyze the students' scores in pre-test and post-test, and between experimental class and control class. It aimed to find out the significant improvement of students' reading comprehension.

\subsubsection{The result of the pre-test}


The result of the reading comprehension test in the pre-test shows a typical figure of the students' ability in reading. There remained some students who got a very poor score. The students still had low ability in reading comprehension. Table 1 explains the facts.

Table 1. The frequency and rate percentage of reading comprehension score in the pre-test

\begin{tabular}{lllllll}
\hline \multirow{2}{*}{ No } & \multirow{3}{*}{ Classification } & Score & \multicolumn{2}{c}{ Cxperimental } & \multicolumn{3}{c}{ Control } \\
\cline { 3 - 7 } & & & $\mathrm{F}$ & $(\%)$ & $\mathrm{F}$ & $(\%)$ \\
\hline 1 & Very Good & $86-100$ & 4 & $10.26 \%$ & 5 & $12.82 \%$ \\
2 & Good & $71-85$ & 15 & $38.46 \%$ & 10 & $25.64 \%$ \\
3 & Fair & $56-70$ & 7 & $17.95 \%$ & 9 & $23.08 \%$ \\
4 & Poor & $41-55$ & 8 & $20.51 \%$ & 9 & $23.08 \%$ \\
5 & Very Poor & $<40$ & 5 & $12.82 \%$ & 6 & $15.38 \%$ \\
\hline \multicolumn{2}{r}{ Total } & & 39 & $100 \%$ & 39 & $100 \%$ \\
\hline
\end{tabular}

Table 1 shows the students' scores in the pre-test before giving treatment. In experimental class, there were 4 (10.26\%) out of 39 students were in excellent classification, 15 (38.46\%) out of 39 students were in good classification, 7 (17.95\%) out of 39 students were in fair classification, 8 (20.51\%) out of 39 students was in poor classification, and 5 (12.82\%) out of 39 students was in very poor classification. Meanwhile, in the control class, there were $5(12.82 \%)$ out of 39 students was in excellent classification, 10 (25.64\%) out of 39 students were in good classification, 9 (23.08\%) out of 39 students were in fair classification, 9 (23.08\%) out of 39 students were in poor classification, and $6(15.38 \%)$ out of 39 students was in very poor classification. It meant that before giving treatment, the reading comprehension of the students' score in both experimental class and control class was categorized good classification with percentage in experimental class (38.46\%) and control class (25.64\%). However, most of the students in both classes were still low in reading comprehension skills.

Furthermore, the score of the student in the pre-test was analyzed by using the standard score of National Education of Indonesia (Departemen Pendidikan Nasional Republik Indonesia). Table 2 presents the students' level achievement before being given treatment.

Table 2. The distribution of students' reading comprehension score in pre-test Score

\begin{tabular}{lllll}
\hline & \multicolumn{3}{c}{ Experimental Class } & \multicolumn{3}{l}{ Control Class } \\
\cline { 2 - 5 } Score & $\mathrm{F}$ & $(\%)$ & $\mathrm{F}$ & $(\%)$ \\
\hline$>70$ & 19 & $48.72 \%$ & 15 & $38.46 \%$ \\
$<70$ & 20 & $51.28 \%$ & 24 & $61.54 \%$ \\
\hline Total & 39 & $100 \%$ & 39 & $100 \%$ \\
\hline
\end{tabular}

Table 2 exhibits that the distribution of the students' scores before being given the treatments. It can be seen that there were nineteen students (48.72\%) in the experimental class whose scores were higher than seventy, the national passing standard. There were twenty students (51.28\%) whose scores were lower than 70 . In the control group, however, there were fifteen students (38.46\%) whose scores higher than seventy, and there were 24 students $(61.54 \%)$ whose scores were lower than seventy. From the data above, it can be concluded that there were more than $50 \%$ of students, both experimental group and control group, failed in reading comprehension lessons.

\subsubsection{The result of the post-test}

The researcher conducted a post-test to measure the improvement of students in reading comprehension at the eighth-year students of Junior High Schools of Parepare and to make sure the improvement of their reading comprehension after they are taught reading through the CIRC method. 


\begin{tabular}{|c|c|c|c|c|c|c|}
\hline \multirow[t]{2}{*}{ No } & \multirow[t]{2}{*}{ Classification } & \multirow[t]{2}{*}{ Score } & \multicolumn{2}{|c|}{$\begin{array}{c}\text { Experimental } \\
\text { Class }\end{array}$} & \multicolumn{2}{|c|}{$\begin{array}{c}\text { Control } \\
\text { Class } \\
\end{array}$} \\
\hline & & & $\mathrm{F}$ & $(\%)$ & $\mathrm{F}$ & $(\%)$ \\
\hline 1 & Very Good & $86-100$ & 7 & $17.95 \%$ & 6 & $15.38 \%$ \\
\hline 2 & Good & $71-85$ & 21 & $53.84 \%$ & 11 & $28.21 \%$ \\
\hline 3 & Fair & $56-70$ & 7 & $17.95 \%$ & 10 & $25.64 \%$ \\
\hline 4 & Poor & $41-55$ & 4 & $10.26 \%$ & 10 & $25.64 \%$ \\
\hline 5 & Very Poor & $<40$ & 0 & $0 \%$ & 2 & $5.13 \%$ \\
\hline \multicolumn{2}{|c|}{ Total } & & 39 & $100 \%$ & 39 & $100 \%$ \\
\hline
\end{tabular}

Table 3 figures out the frequency and rate percentage of the score in post-test were for the experimental group and the control one. There were seven students (17.95\%) out of 39 students who were in excellent classification, 21 (53.84\%) out of 39 students were in good classification, 7 (17.95\%) out of 39 students were in fair classification, 4 (10.26\%) out of 39 students were in poor classification, and no students were in very poor classification. Meanwhile, in the control class, there were six (15.38\%) out of 39 students were in very good rating, 11 (28.21\%) out of 39 students were in good classification, 10 (25.64\%) out of 39 students were in fair classification, 10 (25.64\%) out of 39 students were in poor classification, and 2 (5.13\%) out of 39 students was in very poor rating.

The data exhibit that after experimenting with the method to the respondents, the learners' reading comprehension of both groups was improving. However, the levels of improvement were different. Most students' scores in experimental were categorized into good and very good classification. The progress between before and after getting treatments through the CIRC method was significantly different, from (38.46\%) to (53.84\%). Even though the reading comprehension scores of students in the control group also improved, but it remains little progress. It was proved by most of the students in control class before and after getting treatment through individual learning was classified as good classification with percentage improvement only (25.64\%) to (30.54\%).

Afterward, the score of each student in the post-test was analyzed by using the standard rating of the National Standard of Indonesia. Therefore, it can be known the level of the students' success after being given the treatments that can be seen in the table below:

Table 4. The distribution of students' reading comprehension scores in post-test

$$
\text { Score }
$$

\begin{tabular}{|c|c|c|c|c|}
\hline \multirow[b]{2}{*}{ Score } & \multicolumn{2}{|c|}{ Experimental Class } & \multicolumn{2}{|l|}{ Control Class } \\
\hline & $\mathrm{F}$ & $(\%)$ & $\mathrm{F}$ & $(\%)$ \\
\hline$>70$ & 28 & $71.79 \%$ & 17 & $43.59 \%$ \\
\hline$<70$ & 11 & $28.21 \%$ & 22 & $56.41 \%$ \\
\hline Total & 39 & $100 \%$ & 39 & $100 \%$ \\
\hline
\end{tabular}

Note: 70 is the score for passing grade standard (National Education standard of Indonesia, 2005)

The table.4 shows the distribution of the students' scores after being given the treatments. It can be seen that in the experimental class that there were 28 students (71.79\%) whose scores were higher than 70, and there were 11 students (28.21\%) whose scores were lower than 70 (fair level). While in the control class, there were 17 students (43.59\%) whose scores were higher than 70 , and there were 22 students (56.41\%) whose scores were lower than 70 . From the data, it can be inferred that the cooperative, integrated reading and composition ( $\mathrm{CIRC}$ ) method can significantly improve the reading comprehension skill of the eighth-year students of Junior High Schools of Parepare.

Table. 5. The students' reading improvement progress 


\begin{tabular}{llll}
\hline Sample & Pre-test & Post-test & Gain score \\
\hline Experimental & 67.56 & 76.79 & 9.23 \\
Control & 63.08 & 69.36 & 6.28 \\
\hline
\end{tabular}

Table 5 reveals that the gain score in the experimental group (9.23) was higher than the control class (6.28). It means that the improvement of reading comprehension in the experimental group was more significant than in the control group. In fact, the students who were taught through the cooperative, integrated reading and composition (CIRC) method got higher improvement progress in reading comprehension than the students who were taught through individual learning.

\subsubsection{The hypothesis testing}

The research conducted statistical testing, a hypothesis testing, to determine on what is the level significance of the difference of both groups' scores. It was used to prove whether the hypotheses proposed by the researcher were accepted or not. The researcher used a t-test for an independent sample to find out the significance of the treatment effect. The hypothesis was analyzed at the significant level at alfa 0.05 and degree of freedom $(\mathrm{df}) \mathrm{N} 1+\mathrm{N} 2-2=76$. The result is shown in the following table:

Table 6. The hypothesis testing

\begin{tabular}{lcc}
\hline Test & t-test value & t-table value \\
\hline Pre-test & 1.064 & 1.992 \\
Post-test & 2.152 & 1.992 \\
\hline
\end{tabular}

Table 6 indicated that the t-test value (2.152) in the post-test was greater than the t-table value (1.992). It denoted that the null hypothesis $(\mathrm{Ho})$ was rejected, and the alternative hypothesis $(\mathrm{H} 1)$ was accepted. It meant that the cooperative, integrated reading and composition (CIRC) method could improve reading comprehension of the Junior High Schools of Parepare, Indonesia significantly.

\subsection{Discussion}

Through the CIRC method, the researcher was able to manage the students to work in a pair reading group. As revealed by Slavin (2005: 315) for the experimental group, firstly, the researcher gave an introduction and explanation about the materials in reading comprehension. This step provided an opportunity for students to reveal the fundamental knowledge and develop new knowledge. Secondly, the researcher gave reading narrative texts and encouraged students to read books in pairs. While in control class, the learners were explained the reading material through individual learning. The students were designed to work in all activities in the teaching and learning process through individually without group discussion. First, the researcher presented a recognition about the materials and asked the students to read the text. After reading the text, the researcher helped the students to understand unfamiliar vocabulary on the text and corrected the students spelling. Then, the students worked individually to summarize the main points of the story and retold their results. Next, the researcher gave a worksheet to students. In the last step, the researcher presented a review of the subject.

After conducting the treatments and tests in both experimental and control classes, the researcher compared the result of the tests and found some facts. Before giving the procedure, the students' mean score was only 67.15 , with the standard deviation being 16.74. After providing the treatment, their mean score was76.79, with a standard deviation was 13.98 . It showed that after getting the treatment through the cooperative, integrated reading and composition (CIRC) method, the students undergo improvement. It is similar to the finding of Rajaee (2016). She stated that the experimental group (i.e., learners who received cooperative learning instruction) outperformed the control group (i.e., those learners who received traditional lecture instruction) in the reading comprehension test.

According to Nihalani et Al. (2010), this improvement happened because the collaborative learning group method generated opportunities for the students to understand the reading text more. In this case, the students were engaged in pairs and group discussions (Masnaini, et al., 2018). The students shared the ideas and worked in a group if they found problems in comprehending the text. Therefore, the students had a much deeper understanding of the text that they had read. Slavin (1995) said that cooperative learning organizes students into small groups, which then work together to help one another learn academic content. 
Besides, the CIRC method also made all the learning process more meaningful for the students so that the learning outcomes of the students will be able to last longer.

The conclusion is drawn by various researchers who also supported this research. Gupta \& Jyoti (2014) investigated the impact of CIRC on reading comprehension achievement and found statistically significant differences between control and experimental groups. Similarly, Durukan (2011) also revealed that the CIRC method was more effective than a traditional teaching method. They concluded the students who were taught English through the cooperative, integrated reading and composition (CIRC) method showed significant improvement in their reading comprehension achievement. Furthermore, Abdul (2014) also concluded that a positive effect and significant difference was found in favor of the cooperative learning method that was combined with directed reading thinking activity.

Other researchers of reading comprehension also researched the other method. Isikdogan \& Tevhide (2010) used a story-map method in their research. They found that the mean ranks up from 8.36 to 11.00. In their study, they taught reading comprehension to the students by filling a graphic organizer with the main point of the text. The difference with this research is in the CIRC method. The students synthesize the text based on the ideas from the group discussion. They had responsible and helped each other to achieve the group goal. Joliffe (2007:3) states that cooperative learning requires pupils to work in a small group to sustain each other to improve their education and those of others. They tried to comprehend the text by arguing and sharing their ideas. Therefore, it makes the students have a much deeper understanding of the text than just filling graphic organizer.

\subsection{Pedagogical implication}

The result of this research are expected to be useful information for the practitioners of English language teaching, for example, teachers, curriculum designers of English language teaching, and researchers English language teaching (Grabe, 2004). For the English teachers, the result of this research will be a helpful reference on teaching reading strategy. This result issue will be a part of teachers' properties in developing the knowledge and experience of teaching reading. On other expectation of this result is the teacher, which is more powerful to create many solutions for the students' problem on comprehending the reading text. For curriculum designers, the result of this study will give more contribution to constructing the conceptual issue on teaching reading implementation (Mooney \& Mausbach, (2008). Through the results of this study, the concept of the framework of thinking in learning reading strategy will be more expanded and easily assessed by the teachers, Mudzielwana (2017). For the future researcher, the result of this study is expected to be one of the references on conducting research on reading study.

\section{Conclusion}

Considering the result of the data analysis and the discussion of the effect in the previous chapter, the researcher concluded that the cooperative, integrated reading and composition (CIRC) method improved the reading comprehension of the eighth-year students of Junior High Schools of Parepare significantly. As s, Kamisah (2013) stated that complex learning activities could develop creative thinking where it is quite useful in the treatment groups, (the way of student thinking skills have changed significantly. It was proved by the difference between pre-test and post-test results in experimental and control classes. While the result of the ttest in the post-test was 2.152 and the $\mathrm{t}$-table was 1.992. It showed that the $\mathrm{t}$-test value was higher than the $\mathrm{t}$-table value. By correlating this result with the testing hypothesis, it indicated that the null hypothesis $(\mathrm{HO})$ was rejected and the alternative one (H1) was accepted. Also, the mean score of post-test in experimental class 76.79 was higher than the scoring standard of Departemen Pendidikan Nasional Republik Indonesia (70.00). It showed that the reading comprehension of the eighth-year students of Indonesian learners improved significantly through the cooperative, integrated reading and composition (CIRC) method.

\section{Suggestion}

Teachers of English should be creative and innovative to manage the materials for teaching reading comprehension. Teachers and organizers of schools are expected to modify and give information about of CIRC method in teaching English, especially in teaching reading comprehension (Zainuddin, 2015). Creative students are expected to build a positive activity where students can practice, give their ideas, aspirations, and opinions that can improve their reading comprehension. The curriculum designer is suggested to make cooperative, integrated reading and composition (CIRC) method as a method in teaching process especially in teaching reading comprehension. It is recommended to be considered in arranging and designing a curriculum to improve the quality of teaching and learning in the future.

Next researchers are suggested to use cooperative learning by applying another method in teaching reading comprehension

\section{References}

[1] Akbar, S.R, Taqi.H. A, Akbar. A.A, Sadeq. T.M (2015) Does E-Reading Enhance Reading Fluency ? English Language Teaching, doi:10.5539/elt.v8n5p195 URL: http://dx.doi.org/10.5539/elt.v8n5p195 
[2] Alberto, P. A., Connor, C. M., Compton, D. L., \& O'Connor, R. E. (n.d.). Improving Reading Outcomes for Students with or at Risk for Reading Disabilities: Institution of Educational Sciences, 1-78. https://ies.ed.gov/ncser/pubs/20143000/pdf/20143000.pdf

[3] Alhaisoni, E. (2017). Prior knowledge in EFL reading comprehension: Native and nonnative EFL teachers' perceptions, classroom strategies and difficulties encountered. International Journal on Studies in English Language and Literature, 5(1), 30-41. dhttps://doi.org/10.20431/2347-3134.050100

[4] Zarei, A. (2012). The Effects of STAD and CIRC on L2 Reading Comprehension and Vocabulary Learning. Frontiers of Language and Teaching, 3, 161-173. www.ikiu.ac.ir/public-files/profiles/items/090ad_1360578426.pdf

[5] Anderson M and Richard K. (1985). Definition Becoming a Nation of Readers: The Report of the Commission on Reading. from https://files.eric.ed.gov/fulltext/ED253865.pdf

[6] Kispal. A, (2008). Research Report DCSF-RR031; Effective Teaching of Inference Skills for Reading, National Foundation for Educational Research, https://files.eric.ed.gov/fulltext/ED501868.pdf

[7] Azmuddin, R. A. (2014). Ruhil Amal Azmuddin, (May). Extensive Reading Using Graded Readers, International Journal of Research In Social Sciences. www.ijsk.org/ijrss

[8] Bamford, J., \& Day, R. R. (2004). Extensive Reading Activities for Teaching Language Edited by. assets.cambridge.org/0521016517/sample/0521016517WS.pdf

[9] Brown, H. D. (2007). Teaching by Principles, Second Edition. Teaching by Principles An Interactive Approach to Language Pedagogy.

[10] Castles, A., Rastle, K., \& Nation, K. (2018). Ending the Reading Wars: Reading Acquisition From Novice to Expert. Psychological Science in the Public Interest, 19(1), 5-51. https://doi.org/10.1177/1529100618772271

[11] Channa, M. A., Nordin, Z. S., Simming, I. A., \& Chandio, A. A. (2016). A Qualitative Study of Reading Comprehension: An Insight from Pakistani Context Bridging the Needs of Engineering Students. International Journal of English Linguistics, 6(2), 85. https://doi.org/10.5539/ijel.v6n2p85

[12] Cruickshank, R. D., Jenkins, B. D., Metcalf, K. K. (2006). The act of teaching (4th ed.). New York: McGraw Hill.

[13] Derinalp, P. (2021). Indonesian novice EFL teachers' understanding of and engagement in reflective practice: An exploratory study. White Rose eThesis Online.

[14] Erhan, D. (2011). Effects of Cooperative Integrated Reading and Composition (CIRC) Technique on Reading-Writing Skills. Educational Research and Reviews, 6(1), 102-109.

[15] Gay, L.R. (2012). Educational Research: Competencies for Analysis, \& Application, Tenth Edition, Charles E. Merril Publishing Company.

[16] Grellet, F (1981). Developing Reading Skill A Practical Guide to Reading Comprehension Exercise, UK: Cambridge University Press

[17] Grabe, W.\& Stoller, F.L. (2011). Teaching and Researching Reading. Second Edition. New York: Rutledge.

[18] Grabe, W. (2004). Research on Teaching Reading. Annual Review of Applied Linguistics 24(1): 44 - 69. March 2004 with 4,927 Reads. DOI:10.1017/S0267190504000030, https://www.researchgate.net/publication/231743766

[19] Gupta, M., \& Ahuja, J. (2015). Cooperative integrated reading composition ( CIRC ): improving achievement in English writing composition among seventh graders. Issues and Ideas in Education, 3(1), 49-53. https://doi.org/10.15415/iie.2015.31004

[20] Goodman, K.S. (1995). The reading process. New York: Cambridge University Press.

[21] Halonen-Akatwijuka, M., \& Propper, C. (2012). Competition, Equity and Quality in Health Care, (12), 29 pages.

[22] Healy, C. (2002). Reading: What the Experts Say the Lowdown on the National Reading Pane. PEATC.

[23] Isikdogan, N. \& Tevhide, K. (2010). Investigation of the Effectiveness of the Story-Map Method on Reading Comprehension Skills among Students with Mental Retardation.

[24] Wanzek.J. (2014). Disabilities: Meaningful Impacts,29(2),46-53. https://doi.org/10.1111/ldrp.

[25] Harmer. J. (1998). How to Teach English.New York: Longman Press

[26] Harmer. J. (2001). How to Teach English-Longman Publishing Group (1997).pdf.

[27] Joliffe, W. (2007). Cooperative Learning in the Classroom: Putting it into Practice. London: Paul Chapman Publishing.

[28] Kemendikbud Republik Indonesian. (2014) Peraturan Menteri Pendidikan Dan Kebudayaan Republik Indonesia nomor 104 tahun 2014. Tentang Penilaian Hasil Belajar Oleh Pendidik Pada Pendidikan Dasar Dan Pendidikan Menengah (National Education of Indonesia. NO. 104. 2014, 12-13) file:///C:/Users/ASUS/Downloads/Documents/Permendikbud104-2014PenilaianHasilBelajar

[29] Latifa, A., Rahman, A., Hamra, A., Jabu, B., \& Nur, R. (2015). Developing a Practical Rating Rubric of SpeakingTest for University Students of English in Parepare, Indonesia. English Language Teaching 8(6), 166-177. https://doi.org/10.5539/elt.v8n6p166

[30] Miftah, M. Z. (2015). Implementation of Intensive-Extensive Reading Strategy To Improve Reading Comprehension. Journal on English as a Foreign Language, 3(1), 21. https://doi.org/10.23971/jefl.v3i1.59

[31] Moone.N.J \& Mausbac A.T (2008). Developing Curriculum Leadership and Design. Align the Design.https://shop.ascd.org/Default.aspx?TabID=55\&Productld=934\&Align-the-Design:-A-Blueprint-for-School-Improvement

[32] Mudra, H. (2020). Digital Literacy Among Young Learners: How Do Efl Teachers And Learners View Its Benefits And Barriers?. The Journal of Teaching English with Technology. 20(3): 3-24.

[33] Nihalani, P. K., Wilson, H. E., Thomas, G., \& Robinson, D. H. (2010). What determines high- and low-performing groups? Journal of Advanced Academics, 21, 500-529.

[34] Mudzielwana. N.P. (2017). Towards a Theoretical Framework for Teaching Reading Comprehension: A Case Study of Three Rural Primary Schools. Studies of Tribes and Tribals Journal.

[35] Prowse, P. (2005). Bristol murder, 87 Macmillan.

[36] Riazi, S. M. A. (2017). The Impact of Text Length on EFL Students' Reading Comprehension, 91, 399-404.

[37] Richards, J. C. (2010). L Longman Language \& Applied Linguistics.

[38] Richardson, J.S., \& Morgan, R.F. (2003). Reading to learn in the content areas. Belmont, C. A.: Thomson.

[39] Sevilla $M, H$. (2017). Effects of scaffolded intensive reading on students' reading comprehension performance. Actualidades Investigativas En Educación, 17(1). https://doi.org/10.15517/aie.v17i1.27204

[40] Slavin, R. E. (1995). Cooperative Learning: Theory, research, and practice. (2ndEdition). 
[41] Slavin, R.E. (1996). Education for all. Denhaag: Swets and Zeitlinger BV.

[42] Slavin, R. E. (2006). Educational Psychology: Theory and Practice. Eighth Edition. Boston: Pearson.

[43] St Clair-Thompson, H., Graham, A., \& Marsham, S. (2017). Exploring the Reading Practices of Undergraduate Students. Education Inquiry, 9(3),1-15.https://doi.org/ 10.1080/ 20004508.2017. 1380487

[44] Stevens, R. J., Madden, N. A., Slavin, R. E., \& Farnish, A. M. (1987). Cooperative integrated reading and composition: Two field experiments. Reading Research F. Quarterly, 22(4), 433-454.

[45] Subramanyam, R. (2013). Art of reading a journal article: Methodically and effectively. Journal of Oral and Maxillofacial Pathology, 17(1), 65. https://doi.org/10.4103/0973-029X.110733

[46] Torgesen, J. K. (2006). A Comprehensive K-3 Reading Assessment Plan: Guidance for School Leader. Portsmouth, NH. RMC Research Corporation Center on Instruction.

[47] Vygotsky, L. S. (1978). Mind in society: The development of higher psychological processes. Cambridge, MA: Harvard University Press.

[48] Wicramaarachchi, T. I. (2016). "I Can't Read This! It's So Difficult!" - The Impact of the Difficulty of Texts on ESL Reading Comprehension The Asian EFL Journal Professional Teaching Articles July 2016 Issue 93, (93), 1-41.

[49] Woolley, G. (Ed) 2011. Reading Comprehension: Assisting Children with Learning Difficulties. (pp. 15-34. DOI: 10.1007/978-94-007-11747_2).

[50] Zainuddin M, (2015). The Effect of Cooperative Integrated Reading and Composition Technique on Students' Reading Descriptive Text Achievement. English Language Teaching. Canadian http://dx.doi.org/10.5539/elt.v8n5p11 